\title{
Thiohalocapsa marina sp. nov., from an Indian marine aquaculture pond
}

\author{
P. Anil Kumar, ${ }^{1}$ T. N. R. Srinivas, ${ }^{1}$ V. Thiel, ${ }^{2}$ M. Tank, ${ }^{2}$ Ch. Sasikala, ${ }^{1}$ \\ Ch. V. Ramana ${ }^{3}$ and J. F. Imhoff ${ }^{2}$ \\ ${ }^{1}$ Bacterial Discovery Laboratory, Centre for Environment, Institute of Science and Technology, \\ J. N. T. University, Kukatpally, Hyderabad 500 085, India \\ ${ }^{2}$ Leibniz-Institut für Meereswissenschaften IFM-GEOMAR, Marine Mikrobiologie, Düsternbrooker \\ Weg 20, D-24105 Kiel, Germany \\ ${ }^{3}$ Department of Plant Sciences, School of Life Sciences, University of Hyderabad, PO Central \\ University, Hyderabad 500 046, India
}

Correspondence

Ch. Sasikala

r449@sify.com or

sasi449@yahoo.ie
The genus Thiohalocapsa was established to separate species of purple sulfur bacteria from other species of the genus Thiocapsa based on their halophilic growth response, lack of gas vesicles, large phylogenetic distance and clustering with marine and halophilic strains (Imhoff et al., 1998). At present, the genus Thiohalocapsa comprises only one species, Thiohalocapsa halophila (Imhoff et al., 1998; originally described as Thiocapsa halophila Caumette et al. 1991).

Strain $\mathrm{JA}_{142^{\mathrm{T}}}$ was isolated from photolithoautotrophic enrichments with $2 \% \mathrm{NaCl}(\mathrm{w} / \mathrm{v})$ of anoxic sediment and water (sample properties: $\mathrm{pH} 7.0$, salinity $2 \%$ and temperature $30{ }^{\circ} \mathrm{C}$ ) from a marine aquaculture pond near Bheemli, Visakhapatnam, India $\left(\begin{array}{llllll}17^{\circ} & 54^{\prime} \mathrm{N} & 83^{\circ} & 27^{\prime} & \mathrm{E}\end{array}\right)$. Purification was achieved by repeated agar-shake dilution series (Pfennig \& Trüper, 1992; Imhoff, 1988; Trüper,

The GenBank/EMBL/DDBJ accession number for the 16S rRNA gene sequence of strain $\mathrm{JA} 142^{\top}$ is $\mathrm{AM} 491592$.

A phase-contrast micrograph of cells of strain $\mathrm{JA} 142^{\top}$, whole-cell and acetone absorption spectra and 16S rRNA gene sequence-based neighbour-joining, maximum-likelihood, minimum-evolution and maximum-parsimony trees are available as supplementary material with the online version of this paper.
1970). Polyphasic taxonomic studies and spectral analysis were carried out as described earlier (Anil Kumar et al., 2007a, 2008). Utilization of organic compounds as carbon sources/electron donors for phototrophic growth was tested in the presence of yeast extract $(0.03 \%$, w/v) without any additional carbon source/electron donor. The concentrations of these compounds were $1 \mathrm{mM}$ benzoate, $0.1 \%(\mathrm{v} / \mathrm{v})$ for formic acid, propionic acid, butyric acid, caproic acid, valeric acid, lactic acid, glycerol, methanol and ethanol and $0.3 \%(\mathrm{w} / \mathrm{v})$ for the other organic compounds tested.

Cells of strain $\mathrm{JA}_{142^{\mathrm{T}}}$ were spherical, non-motile, 1.5$2.0 \mu \mathrm{m}$ in diameter and multiplied by binary fission (Supplementary Fig. S1, available in IJSEM Online). Electron photomicrographs of ultrathin sections of the cells revealed a vesicular type of internal membranes. Strain $\mathrm{JA} 142^{\mathrm{T}}$ was able to grow photolithoautotrophically [anaerobic, light $\left(30 \mu \mathrm{E} \mathrm{m} \mathrm{m}^{-2} \mathrm{~s}^{-1}\right), \mathrm{Na}_{2} \mathrm{~S} .9 \mathrm{H}_{2} \mathrm{O} \quad(2 \mathrm{mM}) /$ $\mathrm{Na}_{2} \mathrm{~S}_{2} \mathrm{O}_{3} \cdot 5 \mathrm{H}_{2} \mathrm{O}$ (5 mM) and $\left.\mathrm{NaHCO}_{3} \quad(12 \mathrm{mM})\right]$. Phototrophic growth (Table 1) in the presence of bicarbonate $(12 \mathrm{mM})$ (photomixotrophy) and $\mathrm{Na}_{2} \mathrm{~S} .9 \mathrm{H}_{2} \mathrm{O}$ $(0.5 \mathrm{mM})$ was observed with acetate, pyruvate, lactate, fumarate, succinate, glucose and Casamino acids. 
Table 1. Differential characteristics between strain $\mathrm{JA} 142^{\top}$ and species of the genera Thiohalocapsa and Halochromatium

Strain/species: 1, JA142 ${ }^{\mathrm{T}}$; 2, Thc. halophila; 3, Hch. roseum; 4, Hch. salexigens; 5, Hch. glycolicum. Data for Hch. roseum were taken from Anil Kumar et al. (2007b); data for the other reference species were taken from Imhoff (2005). Cells of all taxa studied divide by binary fission. All strains have internal membranes of the vesicular type. $\mathrm{Na}_{2} \mathrm{~S}$ and thiosulfate are utilized by all strains. Organic substrate utilization was tested in the presence of sulfide and bicarbonate. Propionate, butyrate, ethanol, propanol and crotonate were not utilized by any of the strains. + , Substrate utilized or present; -, substrate not utilized or absent; (+), weak growth; NR, not reported.

\begin{tabular}{|c|c|c|c|c|c|}
\hline Characteristic & 1 & 2 & 3 & 4 & 5 \\
\hline Cell shape & Sphere & Sphere & Rod & Rod & Rod \\
\hline Motility & - & - & - & + & + \\
\hline Cell diameter/size $(\mu \mathrm{m})$ & $1.5-2.0$ & $1.5-2.5$ & $2.0-3.0 \times 3.0-5.0$ & $2.0-2.5 \times 4.0-7.5$ & $0.8-1.0 \times 2.0-4.0$ \\
\hline Gas vesicles & - & - & + & - & - \\
\hline Colour of cell suspension & Purple-red & Purple-red & Purple-pink & Pink, rose red & Pink, pinkish red \\
\hline Carotenoid group & $(\text { Okenone })^{*}$ & Okenone & Okenone & Spirilloxanthin & Spirilloxanthin \\
\hline DNA G $+\mathrm{C}$ content $(\mathrm{mol} \%)$ & 64.8 & $65.9-66.6$ & 64 & 64.6 & $66.1-66.5$ \\
\hline Vitamin $B_{12}$ requirement & - & - & + & + & - \\
\hline Chemolithotrophic growth & - & + & - & + & + \\
\hline pH optimum (range) & $7.5(6.5-8.5)$ & $7.0(6.0-8.0)$ & $7.5(7-8)$ & $7.4-7.6(7.0-8.0)$ & $7.2-7.4(6.2-9.0)$ \\
\hline Temperature optimum $\left({ }^{\circ} \mathrm{C}\right)$ & $25-30$ & $20-30$ & 27 & $20-30$ & $25-35$ \\
\hline $\mathrm{NaCl}$ optimum (range) $(\%, \mathrm{w} / \mathrm{v})$ & $2(1-6)$ & $4-8(3-20)$ & $1.5-2.5(1-3)$ & $8-11(4-20)$ & $4-6(2-20)$ \\
\hline \multicolumn{6}{|l|}{ Photoassimilation of: } \\
\hline Hydrogen & - & + & NR & + & + \\
\hline Sulfur & - & + & - & + & + \\
\hline Sulfite & - & + & - & + & + \\
\hline Formate & - & - & - & - & $(+)$ \\
\hline Acetate & + & + & - & + & $(+)$ \\
\hline Pyruvate & + & + & + & + & $(+)$ \\
\hline Lactate & + & + & - & - & - \\
\hline Fumarate & + & - & + & - & + \\
\hline Succinate & + & - & + & - & + \\
\hline Malate & - & - & + & - & - \\
\hline Fructose & - & + & - & - & NR \\
\hline Glucose & + & $(+)$ & - & - & - \\
\hline Glycerol & - & $(+)$ & - & - & + \\
\hline Glycolate & - & - & - & - & + \\
\hline Valerate & - & - & - & - & $\mathrm{NR}$ \\
\hline Casamino acids & + & - & + & - & $(+)$ \\
\hline
\end{tabular}

${ }^{\star}$ According to absorption spectra, the presence of okenone as major carotenoid is likely.

Substrates not utilized included formate, propionate, butyrate, malate, fructose, ethanol, propanol, glycerol and crotonate. Photo-organoheterotrophy [anaerobic, light $\left(30 \mu \mathrm{E} \mathrm{m}^{-2} \mathrm{~s}^{-1}\right)$, pyruvate $(27 \mathrm{mM})$ ], chemolithoautotrophy [aerobic, dark, $\mathrm{Na}_{2} \mathrm{~S}_{2} \mathrm{O}_{3} \cdot 5 \mathrm{H}_{2} \mathrm{O}(5 \mathrm{mM})$ and $\mathrm{NaHCO}_{3}$ $(12 \mathrm{mM})$ ], chemo-organoheterotrophy [aerobic, dark, pyruvate $(27 \mathrm{mM})$ ] and fermentative growth [anaerobic, dark, pyruvate $(27 \mathrm{mM})]$ could not be demonstrated. $\mathrm{Na}_{2} \mathrm{~S} .9 \mathrm{H}_{2} \mathrm{O}$ and $\mathrm{Na}_{2} \mathrm{~S}_{2} \mathrm{O}_{3} \cdot 5 \mathrm{H}_{2} \mathrm{O}$ were utilized as electron donors under photolithoautotrophic conditions with a minimum concentration of $0.5 \mathrm{mM} \mathrm{Na} \mathrm{Na}_{2} \mathrm{~S} .9 \mathrm{H}_{2} \mathrm{O}$ and a tolerance of up to $4 \mathrm{mM}$, while sulfite, elemental sulfur and hydrogen did not support growth. During oxidation of sulfide, elemental sulfur droplets were stored inside the cells. $\mathrm{Na}_{2} \mathrm{~S} \cdot 9 \mathrm{H}_{2} \mathrm{O}$ and $\mathrm{Na}_{2} \mathrm{~S}_{2} \mathrm{O}_{3} \cdot 5 \mathrm{H}_{2} \mathrm{O}$ were utilized as sulfur sources by strain $\mathrm{JA}_{142}{ }^{\mathrm{T}}$, while sulfate, sulfite, thioglycolate and cysteine did not support growth.
Ammonium chloride was utilized as a nitrogen source by strain $\mathrm{JA}_{142^{\mathrm{T}}}$, while nitrate, nitrite, glutamate, glutamine, urea and dinitrogen did not support growth. Strain JA142 ${ }^{\mathrm{T}}$ is a true marine strain; growth occurs at $1.0-6.0 \% \mathrm{NaCl}$ $(\mathrm{w} / \mathrm{v})$ with an optimum at $2.0 \%(\mathrm{w} / \mathrm{v})$. The $\mathrm{pH}$ range for growth of strain $\mathrm{JA} 142^{\mathrm{T}}$ is $\mathrm{pH}$ 6.5-8.5 with an optimum at $\mathrm{pH}$ 7.5. The temperature optimum for growth is $25-30{ }^{\circ} \mathrm{C}$ (range $25-35{ }^{\circ} \mathrm{C}$ ). Strain $\mathrm{JA} 142^{\mathrm{T}}$ does not require vitamins for growth. The colour of the phototrophically grown cell suspension is purple-red. The whole-cell absorption spectrum of strain $\mathrm{JA} 142^{\mathrm{T}}$ exhibited absorption maxima at 395, 509, 584, 803 and $845 \mathrm{~nm}$ and a shoulder at $878 \mathrm{~nm}$, confirming the presence of bacteriochlorophyll $a$ (Supplementary Fig. S2a), and the absorption spectrum for pigments extracted with acetone exhibited maxima at 462 , 488 and $516 \mathrm{~nm}$, indicating the presence of the carotenoid okenone (Supplementary Fig. S2b). 
DNA was extracted and purified by using the Qiagen genomic DNA extraction kit. The DNA base composition of strain $\mathrm{JA}_{142}{ }^{\mathrm{T}}$ was $64.8 \mathrm{~mol} \% \mathrm{G}+\mathrm{C}$ (by HPLC). PCR amplification and 16S rRNA gene sequencing were performed as described previously (Imhoff et al., 1998). Recombinant Taq polymerase was used for PCR, which was started with primers $5^{\prime}$-GTTTGATCCTGGCTCAG-3' and 5'-TACCTTGTTACGACTTCA-3' (Escherichia coli positions 11-27 and 1489-1506, respectively). Sequences were obtained by cycle sequencing with the SequiTherm sequencing kit (Biozym) and the chain termination reaction (Sanger et al., 1977) using an automated laser fluorescence sequencer (Pharmacia). Nearest relatives and sequence similarities were determined by BLAST search (Altschul et al., 1990) and BLAST 2 SEQUENCES alignment (Tatusova \& Madden, 1999). 16S rRNA gene sequences of the closest related type strains belonging to the genera Halochromatium and Thiohalocapsa were newly determined and the corresponding EMBL database entries were updated prior to phylogenetic analysis. 16S rRNA gene sequences of type strains of representative species of the Chromatiaceae and of strain $\mathrm{JA} 142^{\mathrm{T}}$ were aligned using the FASTAlign function of the alignment editor implemented in the ARB software package (http://www.arb-home.de; Ludwig et al., 2004) and refined manually employing secondary structure information. For phylogenetic calculations, the PhyML online version (Guindon et al., 2005), MEGA version 4.0 (Kumar et al., 2004) and the PHYLIP DNAPARS program implemented in ARB (Ludwig et al., 2004) were used. For tree calculation, a character-based method [maximum-likelihood (Felsenstein, 1981)], two distancebased methods [neighbour joining (Saitou \& Nei, 1987) and minimum evolution (Rzhetsky \& Nei, 1993)] as well as a maximum-parsimony method (Eck \& Dayhoff, 1966; Fitch, 1971, 1977) were employed. The Tamura-Nei model was determined as the model best suited for phylogenetic calculation using the program ModelGenerator (Keane et al., 2006). The maximum-likelihood tree was calculated using the TN93 model, six rate categories, gamma distribution parameter alpha $=0.31$ and proportion of invariable sites $=0.43$ as determined by ModelGenerator. For the maximum-likelihood bootstrap analysis, the nonbootstrapped maximum-likelihood tree was used as the starting tree. The neighbour-joining tree was calculated based on distances corrected by the Tamura-Nei nucleotide substitution model, using sites corresponding to the pairwise deletion option, including transition and transversion substitutions, assuming a heterogeneous pattern among lineages and a gamma-distributed substitution rate $($ alpha $=0.31)$. The maximum-parsimony tree was calculated using the 'more thorough search' option and a randomized sequence order.

The 16S rRNA gene sequence analysis revealed that the new isolate belongs to the family Chromatiaceae and is affiliated to a group of marine and halophilic genera including Halochromatium, Marichromatium, Thiorhodovibrio, Rhabdochromatium and Thiohalocapsa. Highest 16S rRNA gene sequence similarity was shared with Thc. halophila DSM $6210^{\mathrm{T}}(97.5 \%)$ and Halochromatium glycolicum $6340^{\mathrm{T}}(97.2 \%)$. Similarity values of $<98.7 \%$ suggest separation at the species level according to Stackebrandt \& Ebers (2006). Phylogenetic analyses (Fig. 1) confirmed a close relationship between strain $\mathrm{JA}_{142^{\mathrm{T}}}$ and both Halochromatium roseum JA134 $4^{\mathrm{T}}$ and Thc. halophila DSM $6210^{\mathrm{T}}$. In all cases, Halochromatium species and Thc. halophila and $\mathrm{JA}_{142}{ }^{\mathrm{T}}$ clustered monophyletically. Additionally, in all trees (Fig. 1 and Supplementary Fig. S3), Halochromatium species formed a tight subcluster, strongly supported by bootstrap analysis, that did not include strain $\mathrm{JA} 142^{\mathrm{T}}$. The distance-based trees further indicate a separate clustering of Thc. halophila and strain $\mathrm{JA} 142^{\mathrm{T}}$. Detailed comparison of $16 \mathrm{~S}$ rRNA gene sequences revealed particular sequence differences in a number of characteristic nucleotide positions of strain $\mathrm{JA} 142^{\mathrm{T}}$ from both Halochromatium species and Thc. halophila DSM $6210^{\mathrm{T}}$ (Table 2). Overall sequence similarity as well as signature nucleotides demonstrate a closer relationship of strain $\mathrm{JA}_{142} 2^{\mathrm{T}}$ to Thc. halophila compared with Halochromatium species (12 nucleotides identical to Thiohalocapsa compared with eight identical nucleotides to Halochromatium; Table 2). However, nine characteristic nucleotides were different from both Thc. halophila and Halochromatium species, which indicates an intermediate or borderline position between known representatives of the two genera. This view is supported by phylogenetic relationships, as demonstrated by phylogenetic trees constructed by a variety of different methods. All methods used (neighbour-joining, minimum-evolution, maximumlikelihood and maximum-parsimony; Fig. 1 and Supplementary Fig. S3) demonstrate the clustering of $\mathrm{JA}_{142^{\mathrm{T}}}$ with Halochromatium and Thc. halophila. Furthermore, all phylogenetic methods strongly support a subcluster of the three known Halochromatium type strains that did not include strain $\mathrm{JA}_{142^{\mathrm{T}}}$ or Thc. halophila.

Sequences of pufLM support the association of the new isolate with the Halochromatium/Thiohalocapsa cluster (not shown). More specifically, they demonstrate a clear relationship to the pufLM sequence of Thc. halophila, but not those of Halochromatium species (M. Tank and J. F. Imhoff, unpublished results). Similarity of the pufLM nucleotide sequence of strain JA142 ${ }^{\mathrm{T}}$ (approx. $1390 \mathrm{bp}$ ) to that of the type strain of Thc. halophila was $88 \%$; similarities to several sequences from Halochromatium species were $84-85 \%$ and to sequences from Thiorhodovibrio species were below $80 \%$.

A value of $70 \%$ DNA relatedness has been used as a benchmark for separation at the species level for a number of years, and a $16 \mathrm{~S}$ rRNA gene sequence similarity of $97 \%$ was regarded as borderline for requiring DNA-DNA hybridization data, assuming that this value more or less coincides with $70 \%$ DNA-DNA relatedness. In their critical analysis, Stackebrandt \& Ebers (2006) carefully compared 16S rRNA gene sequence similarities with DNADNA reassociation values from a great number of 


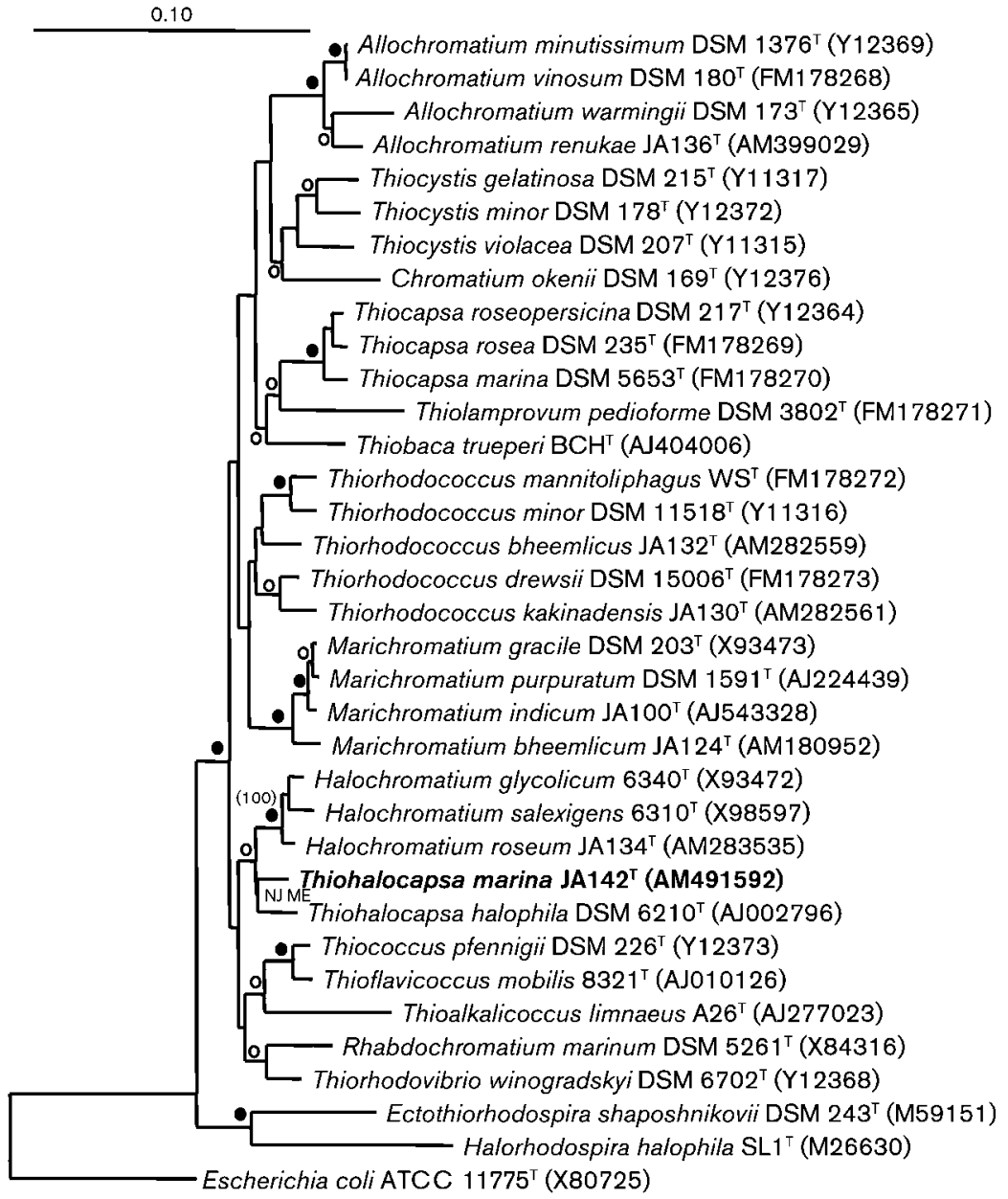

Fig. 1. Phylogenetic consensus tree based on 16S rRNA gene sequences showing the relationship of strain $\mathrm{JA} 142^{\top}$ within the family Chromatiaceae. Phylogenetic trees were calculated by the minimum-evolution and neighbour-joining methods as well as by the maximum-parsimony and maximum-likelihood methods. Tree topology of all four methods was compared and shared nodes are marked in the minimum-evolution tree as follows: nodes supported by all four methods are marked by open circles $(\bigcirc)$; nodes shared by all four methods and supported by bootstrap values $>95 \%$ or $100 \%$ are marked with filled circles [ and (100) , respectively]; a node supported only by the distance-based methods is indicated by NJ ME. Bar, 0.1 substitutions per alignment position. publications. Their convincing result was that, below $98.5 \% 16 \mathrm{~S}$ rRNA gene sequence similarity, there was not a single case where DNA-DNA reassociation was more than $70 \%$, and these authors argued that, with high-quality sequences (as used in this study), 99\% sequence similarity almost excludes reassociation values of $70 \%$ or more. They recommended a $16 \mathrm{~S}$ rRNA gene sequence similarity threshold range of $98.7-99 \%$ as the point at which DNA-DNA reassociation experiments should be mandatory for testing the genomic uniqueness of new isolates. Therefore, the $97.5 \% 16 \mathrm{~S}$ rRNA gene sequence similarity between strain $\mathrm{JA}_{142}{ }^{\mathrm{T}}$ and Thc. halophila DSM $6210^{\mathrm{T}}$ indicates their separation into different species. This is supported by differences in the $\mathrm{G}+\mathrm{C}$ content of the two bacteria of 1.1-1.8 mol\%, by different salt responses and by a number of differences in substrate and electron donor utilization, including the ability to grow chemolithotrophically (Table 1).

Because of the closer association of the novel bacterium with Thc. halophila in terms of both sequence information and phenotypic properties, strain JA $142^{\mathrm{T}}$ is recognized as a member of a novel species of the genus Thiohalocapsa, for which the name Thiohalocapsa marina sp. nov. is proposed.

\section{Description of Thiohalocapsa marina sp. nov.}

Thiohalocapsa marina (ma.ri'na. L. fem. adj. marina pertaining to the sea, marine).

Cells are spherical, $1.5-2.0 \mu \mathrm{m}$ in diameter, non-motile and divide by binary fission. Growth occurs under anaerobic conditions in the light under photolithoautotrophic conditions. In addition, several organic substrates can be photoassimilated. Internal photosynthetic membranes are of the vesicular type. Colour of the phototrophically grown cell suspension is purple-red. The in vivo absorption spectrum of intact cells in sucrose exhibits maxima at 395, 509, 584, 803 and $845 \mathrm{~nm}$, indicating the presence of bacteriochlorophyll $a$ and carotenoids of the okenone series as photosynthetic pigments. The type strain is mesophilic $\left(30{ }^{\circ} \mathrm{C}\right.$ ), with a $\mathrm{pH}$ optimum at 7.5 (range $\mathrm{pH}$ 6.5-8.5). Salt is required for growth of the type strain; growth occurs at $1.0-6.0 \% \mathrm{NaCl}(\mathrm{w} / \mathrm{v})$ with an optimum at $2.0 \%(\mathrm{w} / \mathrm{v})$. Photolithotrophic growth is possible in the presence of bicarbonate $(12 \mathrm{mM})$ and $\mathrm{Na}_{2} \mathrm{~S} .9 \mathrm{H}_{2} \mathrm{O}$ $(0.5 \mathrm{mM})$. A few organic substrates can be photoassimilated in the presence of sulfide and bicarbonate, including acetate, pyruvate, lactate, fumarate, succinate, glucose and Casamino acids. Photo-organoheterotrophy and chemo- 
Table 2. 16S rRNA signature nucleotides for Thiohalocapsa and Halochromatium species

Positions are given according to the sequence of E. coli. Shared nucleotides are highlighted in bold.

\begin{tabular}{|lccc|}
\hline Position & $\begin{array}{c}\text { Halochromatium } \\
(\boldsymbol{n}=\text { 7) }\end{array}$ & $\begin{array}{c}\text { Strain } \\
\text { JA142 }^{\text {T }}\end{array}$ & $\begin{array}{c}\text { Thiohalocapsa } \\
(\boldsymbol{n}=\mathbf{5})\end{array}$ \\
\hline 144 & G & G & A \\
148 & A & G & G \\
223 & G & A & G \\
250 & M U/G $)$ & A & A \\
269 & U & C & U \\
381 & A & A & C \\
444 & G & A & G \\
454 & A & U & A \\
457 & C & U & C \\
473 & U & U & C \\
490 & C & U & C \\
589 & U & C & C \\
590 & G & U & G \\
653 & U & U & C \\
658 & A & C & C \\
660 & G & A & G \\
745 & C & U & C \\
748 & U & G & G \\
838 & U & U & C \\
839 & C & C & U \\
1001 & U & C & C \\
1007 & - & U & U \\
1010 & U & G & G \\
1021 & A & U & U \\
1022 & - & U & U \\
1256 & U & U & C \\
1257 & C & U & U \\
1265 & C & C & A \\
1424 & C & U & U \\
& & & \\
\hline & & & \\
\hline
\end{tabular}

trophy are not detected. No growth factors are required. The DNA base composition of the type strain is $64.8 \mathrm{~mol} \%$ G + C (by HPLC).

The type strain, JA142 ${ }^{\mathrm{T}}\left(=\mathrm{JCM} 14780^{\mathrm{T}}=\mathrm{DSM} 19078^{\mathrm{T}}\right)$, was isolated from a marine aquaculture pond near Bheemli, Visakhapatnam, India.

\section{Acknowledgements}

Financial assistance in the form of an overseas fellowship received from the Department of Biotechnology, Government of India, to Ch.S. is acknowledged. P.A. K. and T.N. R.S. acknowledge the CSIR, Government of India, for the award of SR fellowships.

\section{References}

Altschul, S. F., Gish, W., Miller, W., Myers, E. W. \& Lipman, D. J. (1990). Basic local alignment search tool. J Mol Biol 215, 403-410.

Anil Kumar, P., Sasi Jyothsna, T. S., Srinivas, T. N. R., Sasikala, Ch., Ramana, Ch. V. \& Imhoff, J. F. (2007a). Marichromatium bheemlicum sp. nov., a non-diazotrophic photosynthetic gammaproteobacterium from a marine aquaculture pond. Int J Syst Evol Microbiol 57, 12611265.

Anil Kumar, P., Srinivas, T. N. R., Sasikala, Ch. \& Ramana, Ch. V. (2007b). Halochromatium roseum sp. nov., a non-motile phototrophic gammaproteobacterium with gas vesicles, and emended description of the genus Halochromatium. Int J Syst Evol Microbiol 57, 2110-2113.

Anil Kumar, P., Srinivas, T. N. R., Sasikala, Ch. \& Ramana, Ch. V. (2008). Allochromatium renukae sp. nov. Int J Syst Evol Microbiol 58, 404-407.

Caumette, P., Baulaigue, R. \& Matheron, R. (1991). Thiocapsa halophila sp. nov., a new halophilic phototrophic purple sulfur bacterium. Arch Microbiol 155, 170-176.

Eck, R. V. \& Dayhoff, M. O. (1966). In Atlas of Protein Sequence and Structure, pp. 161-169. Edited by M. O. Dayhoff. Silver Spring, MD: National Biomedical Research Foundation.

Felsenstein, J. (1981). Evolutionary trees from DNA sequences: a maximum likelihood approach. J Mol Evol 17, 368-376.

Fitch, W. M. (1971). Toward defining the course of evolution: minimum change for a specific tree topology. Syst Zool 20, 406-416.

Fitch, W. M. (1977). On the problem of discovering the most parsimonious tree. Am Nat 111, 223-257.

Guindon, S., Lethiec, F., Duroux, P. \& Gascuel, O. (2005). PHYML Online - a web server for fast maximum likelihood-based phylogenetic inference. Nucleic Acids Res 33, W557-W559.

Imhoff, J. F. (1988). Anoxygenic phototrophic bacteria. In Methods in Aquatic Bacteriology, pp. 207-240. Edited by B. Austin. Chichester: Wiley.

Imhoff, J. F. (2005). Family I. Chromatiaceae Bavendamm 1924, $125^{\mathrm{AL}}$ emend. Imhoff 1984b, 339. In Bergey's Manual of Systematic Bacteriology, 2nd edn, vol. 2, part B, pp. 3-9. Edited by D. J. Brenner, N. R. Krieg, J. T. Staley \& G. M. Garrity. New York: Springer.

Imhoff, J. F., Süling, J. \& Petri, R. (1998). Phylogenetic relationships among the Chromatiaceae, their taxonomic reclassification and description of the new genera Thiocapsa, Halochromatium, Isochromatium, Marichromatium, Thiococcus, Thiohalocapsa and Thermochromatium. Int J Syst Bacteriol 48, 1129-1143.

Keane, T. M., Creevey, C. J., Pentony, M. M., Naughton, T. J. \& Mclnerney, J. O. (2006). Assessment of methods for amino acid matrix selection and their use on empirical data shows that ad hoc assumptions for choice of matrix are not justified. BMC Evol Biol 6, 29 .

Kumar, A. S., Tamura, K. \& Nei, M. (2004). MEGA3: integrated software for molecular evolutionary genetics analysis and sequence alignment. Brief Bioinform 5, 150-163.

Ludwig, W., Strunk, O., Westram, R., Richter, L., Meier, H., Yadhukumar, Buchner, A., Lai, T., Steppi, S. \& other authors (2004). ARB: a software environment for sequence data. Nucleic Acids Res 32, 1363-1371.

Pfennig, N. \& Trüper, H. G. (1992). The family Chromatiaceae. In The Prokaryotes. A Handbook on the Biology of Bacteria. Ecophysiology, Isolation, Identification, Applications, 2nd edn, pp. 3200-3221. Edited by A. Balows, H. G. Trüper, M. Dworkin, W. Harder \& K. H. Schleifer. Berlin, Heidelberg \& New York: Springer.

Rzhetsky, A. \& Nei, M. (1993). Theoretical foundation of the minimum-evolution method of phylogenetic inference. Mol Biol Evol 10, 1073-1095.

Saitou, N. \& Nei, M. (1987). The neighbor-joining method: a new method for reconstructing phylogenetic trees. Mol Biol Evol 4, $406-425$. 
Sanger, F., Nicklen, S. \& Coulson, A. R. (1977). DNA sequencing with chain terminating inhibitors. Proc Natl Acad Sci U S A 74, 54635467.

Stackebrandt, E. \& Ebers, J. (2006). Taxonomic parameters revisited: tarnished gold standards. Microbiol Today 33, 152-155.
Tatusova, T. A. \& Madden, T. L. (1999). BLAST 2 sequences - a new tool for comparing protein and nucleotide sequences. FEMS Microbiol Lett 174, 247-250.

Trüper, H. G. (1970). Culture and isolation of phototrophic sulfur bacteria from the marine environment. Helgol Wiss Meeresunters 20, 6-16. 